Patrick Kabeya Mwepu

Patrick Kabeya Mwepu was born in the DRC, received a Ph. D in French language and literature (University of

Cape Town) and was appointed as Senior Lecturer of French Studies at Rhodes University. He has authored several papers on African francophone literature. E-mail:p.mwepu@ru.ac.za; pakabeya@yahoo.fr

\title{
Women and their struggle for emancipation in Lopes' works
}

\section{La femme et sa lutte de libération dans l'œuvre d'Henri Lopes}

Né le 12 septembre 1937 à Kinshasa, en Congo, mais se réclamant de nationalité congolaise de Brazzaville, Henri Lopes est l'un des écrivains africains qui ont non seulement été éduqués en Europe mais en plus ont pu y vivre tout en y produisant une partie de leur œuvre littéraire. A la fois homme politique et écrivain, il est facile de dénicher, à travers sa plume, la description achevée d'une gestion politique postcoloniale despotique à laquelle s'ajoute le manque d'humanisme porté à son paroxysme. Les œuvres comme Tribaliques(1971), La Nouvelle romance(1976), Sanstam-tam (1977) Le Pleurer-Rire (1982) et Sur l'autre rive(1992) constituent à la fois une vision du monde et une appréhension de la réalité totale et englobante d'une Afrique jeune au lendemain des indépendances politiques. Pourtant, bien que l'œuvre de Lopes stigmatise les faiblesses de la classe dirigeante africaine postcoloniale, il est important de remarquer qu'à travers son écriture l'auteur semble être intéressé également par les questions en rapport avec la vision et la critique de la condition de la femme africaine. Sa manière particulière de l'aborder consiste à placer une voix révolutionnaire dans la bouche des femmes elles-mêmes qui parlent de leur condition et cherchent des solutions, bien que l'auteur soit lui-même un homme. Mots clés: La femme africaine, la mission, la quête de l'émancipation.

\section{Women and their struggle for emancipation in Lopes' works}

Born in Kinshasa, Congo, on 12 September 1937, but a national of Congo (Brazzaville), Henri Lopes is one of those African writers who, were not only educated but also lived in Europe where a certain portion of their literary work was produced. Being a politician and writer, one can easily glean, through Lopes' works, a complete picture of despotic postcolonial mismanagement of political affairs coupled with a dire dearth of humanism. Literary works such as Tribaliques (Tribaliks, 1971), La nouvelle Romance (The New Romance, 1976), Sans tam-fam (Without Drum, 1977), Le Pleurer-Rire (The Crying-Laughter, 1982) and Sur I'autre rive (On the Other Shore, 1992) depict a particular worldview as well as an understanding of the overarching reality of a young Africa that had just attained political independence. However, while Lopes' works decry the shortcomings of Africa's postcolonial ruling class, it is important to note that the author appears to pay equal attention to questions relating to the perception and critical analysis of the status of women in Africa. Notwithstanding his male gender status, in his rather original approach, Lopes lends women a revolutionary voice with which they address and search for solutions to their problems themselves. Key words: African women, mission, struggle for emancipation. 
A thorough analysis of Lopes' works apparently makes many readers rediscover a vital experience of a certain traditional Africa. At the same time, it awakens their conscience to the challenges encountered in a changing society. It is also claimed that some others eventually discover the sociological circumstances that might have goaded the author to embark on a revolt aimed at instigating social change in his community, as evidenced in his treatment of issues pertaining to African women, their fundamental role as well as their present and future social status. As it were, the issue of women's emancipation has always been a prolific subject of literary polemics. ${ }^{1}$ However, Lopes' dialectical approach in this regard differs from the rather superficial and classical approach traditionally adopted by certain writers, where real issues relating to the emancipative dimension of writing are not taken into account. Barbara Godard describes this shortcoming, which she ascribes to many romantic writers, in the following terms:

Seldom is female sexuality given space to express itself in an unfettered manner. This should not be surprising at all, since most love stories are narrated from a male perspective. The woman simply plays the role of the other, an object of conquest to be courted or seduced by the protagonist, after which the latter embarks on new conquests. Classical stories narrated from a female perspective exhibit a similar angle, where the central theme revolves around the courted woman who rebuffs all male advances until she is offered the ultimate prize: marriage (Godard 1992: 85).²

For Lopes, however, it is time to challenge this historical apprehension, with a view to fostering some kind of revolution in this arena. This, in Roland Barthes' (1966: 44) terms, entails déplacer la parole (shifting discourse). This discursive shift is used to good effect in Lopes' works in the sense that in spite of the fact that Lopes is a male writer, he uses feminine narrative techniques or feminine discourse, which could be located somewhere in the meanders of a certain perception, couched by Borgamono (1989: 81) in the following terms: "Where the narrator is depicted as female, the novel is intended to make us adopt a female outlook and hear a female voice, in a more or less candid manner." ${ }^{3}$

Many narrators in Lopes' works are women telling stories about other women. One notices that, on occasion, the narrative taps into the subconscious of female characters; this is fostered by the use of the epistolary genre by certain narrators. However, women constitute one of Lopes' most prolific and yet most slippery and subtle themes. Therefore, the subject will be discussed here from several points of view, namely: education, fundamental roles, work as well as various social relations as they are experienced by African women. The last part of the discussion will revolve around the ndoumba, a special category of women, and the divorce as a logical consequence of failed endeavours, a wake-up call among many others, for conscious and lasting emancipation. 


\section{Education or femininity?}

Lopes' works focus primarily on education and teaching. The discerning reader will not fail to notice that Sans tam-tam (Without Drum, 1977) is written against the backdrop of education, to which the author, through Gatsé, the main character of this novel, attaches particular import. It is important to recall that school institution, as exists today, is a recent phenomenon in some parts of Africa. Lopes subscribes to the view that schooling in contemporary Africa is the only way for Africans to attain social and economic development. Nonetheless, a certain social sector seems to be virtually deprived of this privilege: it is the women. As a matter of fact, school education in Africa has been regarded as the preserve of men. In the past, as can still be seen today, society thought that it was sufficient to limit school education to boys while deliberately excluding girls. Lopes' works bring this traditional dimension of African life to the fore by attributing extremely conservative views to a modern-day legislator. The honourable Ngouakou-Ngouakou, the main character of the short story, "Monsieur le député" from the Tribaliques (Tribaliks, 1971) collection of short stories, addresses his daughter and his spouse in the following terms: " - Do not forget that you are a woman. The primary task of a woman is domestic work [...]- Do you really believe that her school leaving certificate will help her keep her husband at home?" (Lopes 1971: 60) ${ }^{4}$

'Keeping the husband at home' is a sociological goal which reveals the ultimate purpose of young girls' education. To the extent that her fundamental purpose is marriage, even the prospective spouse considers schooling as a sacrilege "which erodes a woman's femininity" (qui ôte à la femme sa féminité; Lopes 1976: 16). The same mindset can be gleaned in Awa Keita's mother's views, according to which "a young girl and a prospective wife's place is at home and not at school, since schooling can comprise morality" (Keita 1976: 28). ${ }^{5}$

The logical consequence is that women become incapable of asserting themselves vis-à-vis men. Since their intellect can not be elevated above the level required by men, in their roles as parents or husbands, women are confronted with tasks to perform and thus become incapable of recognising or claiming their rights. The character Mba believes that women whose education has been sacrificed must, as a result, "accept to work, suffer from an early age and let the ndumbas debate about the emancipation of African women" (Lopes, 1971: 17). ${ }^{6}$

According to Lopes, the issue of women's emancipation cannot be dissociated from women's school education. The character, Ngouakou-Ngouakou, also acknowledges this fact, much as his actions betray his words. Similarly, he believes that "it is time to do away with the prejudices which have lead some fathers still today to bar their daughters from furthering their studies and, that through education, women will be in position to emancipate themselves from patriarchal tyranny" (Lopes 1971: 55). ${ }^{7}$ The ultimate purpose of schooling, as defined by this character in Lopes' works, is similar to the one put forward by Bâ, who thought that the goal of women's educa- 
tion was not only to "broaden their perception of the world, while strengthening their character, but also to enhance their qualities by making them the embodiment of universal moral values" (Bâ 1980: 27-8). ${ }^{8}$ Occasionally, Lopes uses female characters that are much more perceptive than men who appear to succumb to the mediocrity of their times. In Le Lys et le Flamboyant (The Lily and the Flamboyant, 1997), for instance, Kolélé comes across as more intelligent than Tomboka, who does not seem to have any sense of insight in the manner in which he addresses people (Lopes, 1997: 372). Wali, the abused spouse of Bienvenu in La nouvelle Romance (The New Romance, 1976), understood the importance of schooling, something she expresses readily in a letter to her friend Elise, where she expresses the view that academic qualifications would be necessary for her to be able "to assert herself in a society that must be destroyed" (s'affirmer dans une sociétéà détruire; Lopes 1976: 193). Awa, in La nouvelle romance (The New Romance, 1976), Marie-Eve, in Sur l'autre rive (On the Other Shore, 1992), Kolélé, in Le Lys et le Flamboyant (The Lily and the Flamboyant, 1997), Appoline and Mbâ, in Tribaliques (Tribaliks, 1971), epitomize an educated femininity whose moral values are a useful resource that could bring about social change. In his analysis of Tribaliques, Leskes makes a similar observation:

Many of Lopes' female characters are sympathetically drawn modern African woman: young, educated in European style schools, and intellectually alert. His attitude towards them is neither paternalistic nor chauvinistic. Women are portrayed as positive forces, necessary to the creation of a modern Africa, rather than as poetic objects representing either the humiliated continent or the hope of the race (Leskes 1987: introductory pages).

Given that traditional education only revolves around marriage, which is considered to be the fundamental role of women, one wonders how women would experience marriage if their intellectual training is minimal or inexistent altogether.

\section{Cinderella or partner?}

Throughout Lopes' novels, the concept of marriage is skewed in favour of men to whom society has given extensive powers; women are reduced to the most insignificant status. Hence, the status of the character Wali is described as "a domestic worker tasked with providing for, taking care of and looking after more children than she would have wished to have and to whom she has not given birth" (Lopes 1976: 14). ${ }^{9}$ Sometimes women are simply viewed as general domestic servants who, for that matter, are responsible for all domestic chores. In Le Chercheur d'Afriques (The Searcher of Africas) André Leclerc talks about his mother who wakes up earlier than his father every day in order to accomplish "tasks which most men would not have endured" (tâches que beaucoup d'hommes n'auraient pas pu supporter; Lopes 1990: 17). 
Such abuse leads certain women to question the basis of biblical teachings, considering that it is "Adam, and not Eve, that God told to earn his bread through toil and sweat" (Lopes 1976: 15). ${ }^{10}$ As far as health is concerned, it so happens that women are much more vulnerable to certain diseases than men because of hard labour (Lopes, 1977: 26). Over and above these laborious tasks, women have to contend with a family life that is characterised by frequent and continuous births to such an extent that one character wonders whether it is reproductive or productive tasks that have destroyed her mother's health (Lopes 1977: 26).

The most arduous tasks, coupled with intensive procreation, bear testimony to the exploitation of women who are condemned to silence vis-à-vis their husbands, fathers or any other man for that matter, as described in Bienvenu's comments:

Women are not of the same species as men. Trying to reason with them would be a futile exercise. They are mostly sensitive. I think for instance that they are subject to the influence of the moon. Just like the sea. Consequently, it is useless to try to explain anything to them during such phases. It is a waste of time. They have to be beaten. Well, well, well. After that they feel relieved. They feel better. Then they can understand everything they are told (Lopes 1976: 19-20). ${ }^{11}$

Bienvenu's attitude is complemented by that of another character, Ngouakou-Ngouakou, who believes that "women must never make remarks to their husbands" (les femmes ne doivent jamais faire des remarques à leurs maris; Lopes 1971: 56). Such reprimands are similar to the ones addressed to Awa Keita by a traditional leader during elections at Singué in Mali in April 1959. Describing this woman, the traditional leader in question used a series of pejorative attributes such as "audacious, cheeky, Satanic and diabolic talk" and he threatened to "get his wives to beat her up if she continued speaking to him" (Keita 1976: 389-90). ${ }^{12}$ Francophone African literature abounds in instances of this kind of total submission on the part of women. Tahar Ben Jelloun specifically deals with this subject in L'enfant de sable (The Sand Child, 1985), La nuit sacrée (The Sacred Night, 1988), and Harrouda (Harrouda, 1985). In the latter novel, it is mentioned that "women were submissive and resigned to their fate: they would not sit at the table with their husbands, who would never compliment them on anything" (Ben Jelloun, 1985: 81). ${ }^{13}$ This thematic similarity adequately demonstrates that Henri Lopes does not deal with a problem that is inherently limited to a world view specifically embedded in the sociology or the cosmogony of the Congo.

One other aspect worthy analyzing is that throughout Lopes' works, certain women's lives are made miserable as a result of the flagrant infidelity of their spouses; such is the fate of many female characters. For instance, in a letter to her friend Awa, Wali strongly denounces her husband infidelity (Lopes 1976: 140).

Lopes' works demonstrate that male infidelity is never socially frowned upon as a form of transgression. Tradition generally allows men to enjoy this kind of freedom. 
The maître d'hôtel in the novel Le Pleurer-Rire does not mince his words on the subject: he contends that "a man who stays with one woman is a disabled person" (un homme qui reste avec une seule femme est un infirme; Lopes 1982: 20).

However, much as some women have learnt to put up with this custom and, thus, find it morally acceptable, Kolélé, in Le Lys et le Flamboyant, considers that custom to be a social oddity and does everything she can, albeit without success, to convert an already indoctrinated social class (Lopes 1997: 356). In Sans tam-tam, Gatsé rationalises polygamy and finds it normal as long as it does not condone the exploitation of women (Lopes 1977: 52). Gatsé is an isolated case, in the sense that polygamy did not make him humiliate his first wife, Sylvie, who he always regarded as good companion (Lopes 1977: 48). While Gatsé continues to maintain a good relationship with his wife, notwithstanding the polygamous marriage, Jupiter, on the other hand, places a high premium on opulence as the best means to subject his partner to systematic exploitation (Lopes 1976: 84). This characteristic dependence situation in which Jupiter's wife is put and which definitely exposes her to exploitation, is similar to Appoline's experience, in the sense that the latter is forced to marry a wealthy abusive man. Whereas this character rationalises her situation by arguing that "if the decision were hers alone to make, she would never have given in", the situation becomes easier to understand especially through the explanation provided by the narrator regarding Appoline's family financial dependency Lopes 1971: 48). ${ }^{14}$ Wali is no exception. Much as she is ill-treated by her husband, Bienvenu, she hesitates to leave him simply because he "maintains her" (la fait vivre; Lopes 1976: 132).

All things considered, the marriage into which the African traditional woman depicted in Lopes' works is forced constitutes an enterprise in which she only plays a secondary role. African society as portrayed in Lopes' works unanimously affords men all kinds of liberties that are scarcely accessible to women. As mothers to an invariably large number of children and hard workers both at home and in the fields, women are subjected to untold drudgery that can only be tolerated by men, provided their egoistic tranquillity is not compromised in the process. In the light of all these trials and tribulations, resulting mainly from an unhealthy co-existence within the household, the disgust of being a wife, as will be demonstrated in this essay, inhabits the conscience of certain women. Wali did not try to conceal this sentiment from her spinster friend, Elise, to whom she reveals her disappointment with marriage (Lopes 1976: 64). But how can one really overcome this deadlock?

\section{Reinventing oneself}

Currently, Africa is characterised more than ever before, by a marriage crisis as evidenced by an ever-increasing divorce rate. While the social structure in traditional Africa used to be relatively stable, notwithstanding the role and the status of women, 
inequality, as experienced today, could be attributed to changes with which society as a whole has to contend. In this regard, Abdoulaye-Bara Diop (1985: 211), believes that "the rise in divorce rates is a consequence of the destruction of traditional structures and values without being replaced with new efficient ones, that would help solve problems confronting groups and individuals today."15

The root cause of this social inequality is obvious: traditional education, based on initiation and submission, no longer suffices for a changing society to modernise further while affirming itself. It has thus become necessary to break away from ancient dogmas. For instance, when Wali is disappointed by her relationship with Bienvenu, she explains her break-up in a letter to Elise, as a gesture of fundamental transformation of society as a whole. During the course of the struggle for change, "African women have a specific role to play, since they are the real slaves" in their society and, for that matter, the only ones that suffer the negative effects of gender inequality (Lopes 1976: 193). ${ }^{16}$

Lopes' works also provide other examples on the quest for gender equality. Society as a whole is perceived by the author as a creation of the past which may need to be destroyed before it can be reconstituted. As the character, Dahounka, puts it, it is a "system that needs to be demolished" (machine à faire sauter; Lopes 1971: 83). In the same vein, Marie-Eve views change as a kind of escape "to reach other shores and to reinvent oneself" (pour aborder d'autres rives et se métamorphoser en une autre; Lopes 1992: 201).

When Lopes uses the formulaic phrase, 'reinventing oneself', one gets the feeling that he aligns himself with surrealists. Jean-Michel Devésa explains the expression changer la vie (changing life) borrowed from Rimbaud, as follows: "Changing life, transforming the world, entailed defining new horizons, mapping out new perspectives, refusing to get bogged down by a life driven by work and wages, tackling social practices, challenging certain kinds of behaviour to which nobody would normally pay attention as they are 'natural' and taken for granted" (Devésa 1994: 10-1). ${ }^{17}$

As far Lopes is concerned, standing up against one's society might foster the idea of creating a new society and defining a new tradition for the future, generally founded on the principle of egalitarianism. This can only be made possible thanks to the nearheroic courage of the few pioneers of a rationalist generation. The character, Wali's view is typical in the sense as she became aware of her condition, she "challenged her husband and by so doing she might have already started to challenge society, which thinks of him as a normal man, not to say a model" (Lopes 1976: 191-2). ${ }^{18}$

In Sur l'autre rive, Madeleine similarly epitomizes this new subjectivity to the extent that while she does not hesitate at all to leave her husband, without any fear of her husband or society, she views her initiative as a consequence of "an irresistible force, somewhere in her bosom which repeatedly tells her to sever ties and leave" (Lopes 1992: 227). ${ }^{19}$ However, in La nouvelle Romance, Awa had understood much earlier than Wali that society was characterised by inequality. Thus, the best way not to show vulnerabil- 
ity was to become educated through studying and reading (Lopes 1976: 59). Apparently, Wali came across the concept of change through travel and multiple encounters (Lopes 1976: 63-4). There is no difference with the male character, Elo, in Tribaliques, who, through his behaviour, displays a change of attitude in his perception of women, which change can be attributed to his long stay in Europe. Essentially, Elo has no qualms about performing certain tasks in the household, which tasks are considered to be a domain restricted to women in his home country in Africa (Lopes 1971: 21).

It should similarly be noted that when Lopes gives a voice to women, be it through letters or conversations, they speak of themselves and of the many problems which they have to endure. This clearly constitutes a transgression of social norms, since in African traditional society women are castigated for merely speaking about their own situation. This stance is aimed at bringing about immediate change in behaviour. Furthermore, an analysis of Lopes' works reveals that ill-defined positions might lead women to rebellion and infidelity. Victorine, a young student, indulges in adultery simply because she thinks that it is unfair for women to be "the only ones bound to be faithful in a relationship" (Lopes 1976: 35) ${ }^{20}$ It is interesting to note that the novel Le Lys et le Flamboyant abounds in cases of separation; divorce is as frequent as marriage to the such an extent that the narrator is compared to "a child with a hundred fathers" (enfant aux cent pères; Lopes 1997: 212). Léon's mother, Houang's mother, and Monette Fragonard have gone through divorce several times (Lopes 1997: 172, 214).

In the light of the above, one could argue that the quest for women's emancipation, discernible in Lopes' works, is already bearing fruit. According to Lopes, contemporary African women are capable of rejecting social taboos and denouncing unfair relationships, as already demonstrated, through discursive ideas formed as a result of internalising precepts embedded in contemporary feminism. Therefore, in order to create a meaningful atmosphere of cooperation, men will have to change. In this regard, Lopes attempts to educate women's minds by inserting philosophical and profoundly academic discourse into the utterances of some of the female characters. He aims to guide women's conscience along the same lines as Mary Kolawole, who essentially agrees with and endorses this approach, in this manner: "Changing women's consciousness is the baseline for changing their attitude to cultural practices that undermine them" (Kolawole 1998: 11). As it were, women will no longer be reduced to the status of 'insensitive objects', since "they feel each and every ounce of their body quiver with every pulse of life" (Mailhot 1964: 54). ${ }^{21}$ As will be demonstrated in the subsequent segment of this paper, Lopes ultimately devotes many lines to describing the status of single women.

"Kindoumba" or freedom?

As a theme, prostitution constitutes a cliché in Francophone African literature. This 
concept has been overworked to the extent of distorting its initial meaning. Congolese literature has even given rise to neologisms denoting female prostitutes: bordel (whorehouse), salope (bitch), trottoire (hooker) etc.

However, though many writers talk of ndoumba, it is interesting to note, as it were, that it is Lopes who endeavours to capture the essence this term from a purely sociological standpoint as well as from a specific worldview. As a sociological concept, prostitution can only be understood in a clearly defined context. Thus, the Tribaliques collection of short stories states the following: "As for the 'noted activists', deep down, they were nice upper class ndumba who could read and write but would not fight for the abolition of polygamy. They used to make fun of married women who thought they could keep their husbands to themselves" (Lopes, 1971: 17). ${ }^{22}$

As could be noticed, the author borrows the notion of $n d u m b a$, a linguistic term from various Bantu languages and linguistic areas, such as Lingala, Kikongo and Ciluba, which he uses liberally. Yet one wonders why the author was so zealous as to keep the term in its original language. According to the author, all indications appear to suggest that there is not a single word in French that could accurately render the meaning of that term. The author is of the view that "it would be malicious to translate ndumba or ndoumba with the term 'prostitute"' (Lopes 1992: 64). ${ }^{23}$ But how does he explain it himself and in which context do the characters use or embody the term? Having depicted ndoumbas in one of her paintings, the character Marie-Eve sheds some light on the subject:

Ndoumbas are in fact great ladies that care about their freedom and who regard marriage as the cemetery of amorous adventures [...] They are not whores! Much as they like to find themselves lovers that have the means to help them live in comfort, none of them is a slave to money. They never surrender to the highest bidder. On the contrary, they choose their partners (they often have several of them just as those men back home who have several 'official' mistresses at the same time), get rid of them whenever they feel like it because they would like to make love to each of those men in a wholehearted manner (Lopes 1992: 64). ${ }^{24}$

This definition is echoed by the narrator's views in Le Lys et le Flamboyant as expressed in the following remarks:

Ndoumbas were not the kind of women whose attention one could get by simply dangling a few bank notes. They would choose their own targets, pounce on them whenever they thought it opportune to do so, made them conform to their whims, made them bow to their needs and then would command and lead them according to their fantasies, whereas the model and faithful spouses, so honourable and vulnerable as they were, would be busy wasting their lives away as housewives (Lopes 1997: 336). ${ }^{25}$ 
In a nutshell, $n$ doumbas somehow distanced themselves from marriage and preferred a life of near-total independence. Thus, the author presents a number of instances of cohabitation between these women and the men of their choice. Elise, a ndoumba, proudly speaks about her life to her friend Awa: "I choose my clients! Not every Tom, Dick or Harry can sleep with Elise - only those who can afford it. Just look carefully; you won't see any old man amongst my lovers. All of them are in their prime, my dear. As for numbers, let's simply say that I am a polygamous woman ...-Polyandrous, rectified Awa" (Lopes 1976: 66). ${ }^{26}$

Kolélé, disguised in this instance as Célimène Tarquin, fully agrees with Elise because the latter expresses opinions akin to those of Houang and asserts her "freedom to choose her prey" (liberté dans le tri de ses proies; Lopes 1997: 236). This illustrates adequately that $n$ doumbas easily succeed where married women flounder. As a result, ndoumbas can never countenance marriage given that "lovers bow to their whims while continuously treating them as fiancées" (Lopes 1976: 64). ${ }^{27}$ The author demonstrates that ndoumbas owe their power to their charm, which they maintain constantly and so meticulously that, hooked on things fabulous as it is, society has elevated them to the status of marvellous beings akin to mermaids, known as "Mami Wata" in local parlance (Lopes 1992: 68). Houang lends a sociological dimension to these water goddesses, who are shrouded in mystery, by likening them to ndoumbas: "Partly woman, partly animal, mermaids of some sort, beautiful, very beautiful, enchanting, blessed with irresistible charm to which even the most faithful husbands would succumb" (Lopes 1997: 150). ${ }^{28}$

Described in this fashion, one wonders if anyone could resist such seductive power. Raphaël in Tribaliques muses over the same question after noticing that students were preoccupied with ndoumbas around the clock (Lopes 1971:27). Incidentally, students are not the only group targeted by these ladies; thousands of senior civil servants also succumb to their charms. Zikisso, a foreign service establishment supervisor (Lopes 1976: 32, 50), the State President, Tonton (Lopes 1982: 105, 258), Bienvenu, the diplomat (Lopes 1976: 116) illustrate the tendency on the part of senior civil servants to succumb to ndoumbas. However, the practice of kindoumba has led to the proliferation of unwanted babies, as evidenced in the case of characters like Bienvenu (Lopes 1976: 152-5), Gatsé's father (Lopes 1977: 25) and Président Tonton Bwakamabé (Lopes 1982: 286), just to mention a few.

All things considered, the analysis of kindoumba presented above deals with unattached women, the ndoumbas. Commenting on Une saison au Congo (A Season in the Congo, 1966) from Aimé Césaire, Suzanne Houyoux explains the term femmes libres (unattached women) in relation to the sociological context of the Congo in the following manner:

Unattached women [...] are a reference to the problem of prostitution in Léopoldville and the traditional custom of ndumba. It was customary for one of the girls in 
the family not to be given in marriage but to practice prostitution, subject to the consent of the council of elders, in order to see to the material comfort of her parents, whereby the presumed parent of her prospective children would become a supplementary source of income and the children would be welcomed with joy, since they would increase the numerical strength of the clan and the community (Houyoux 1993: 52). ${ }^{29}$

It should be noted nonetheless that, in certain circles, this attitude is dictated by the choice of the young girl herself who, for some reason or the other, gives up on the option of marriage. In many instances, this can be attributed to influence from circles frequented by the young girl, especially those of adult professional ndoumbas, disappointment in marriage, infertility, etc.

Furthermore, amongst certain ethnic groups in the Congo, ndoumbas are frowned upon and a person considered being an ndoumba, or a child born out of such a union is ridiculed under the pretext that the ndoumba practice constitutes a transgression of social norms. This phenomenon can thus be discerned through neologisms or derogatory names commonly used to denote this concept, such as those popularised by Congolese writers: bordel (whorehouse or brothel) by Sony Labou Tansi; putain à vie (whore for life) or Satan à mort (downright evil) by Julien Omer Kimbidima, and trottoire (hooker) by Lopes. Traditionally, the status of married women has always been characterised by a tremendous sense of honour, whereas the status of ndoumba represents a sort of insult. Whatever the case may be, it could safely be said that Lopes uses this 'social counter-value' to educate unstable couples. At the end of the day, the issue is not about promoting a counter-value with a view to projecting it as a virtue. On the contrary, the author uses the absurd to demonstrate his ultimate goal of restoring women's rights with particular regard to married women.

However, apart from the professional ndoumba, Lopes' works exhibit a clear tendency on the part of certain married women to engage in adultery. This is the case of Clarisse Obiang (Lopes 1992: 73, 74), Marie-Eve, (Lopes 1992: 176-83, 194-5), Soukali (Lopes 1982: 71), President Tonton's wife (Lopes 1982: 108), Félicité (Lopes 1992: 135), among others. One can also appreciate the author's determination to describe adultery committed by married women, with glee, as a reaction on their part to the attitudes of men and African society as a whole, considering that some men give themselves the liberty to have multiple partners. It is because of this kind of behaviour that "meaningful love is absent in marriage" (l'amour véritable manque dans les mariages; Lopes 1992: 195).

It could be said, by way of conclusion, that the concern regarding the emancipation of African women could be one of the reasons that led Lopes to writing. His male status notwithstanding, the author decided to contribute to the cause for the liberation of African women. To justify his stance, Lopes propounds the view that it is 
possible for a man to be a feminist. He subsequently recalls how "Racine and Shakespeare had brilliantly succeeded in creating female protagonists, just as women writers today encounter the same level of success in depicting male characters in their novels" (Lopes 1993: 84). ${ }^{30}$ The conclusion one can draw from Lopes' works is generally one of a universal nature. Women throughout the world are engaged in a perpetual struggle to emancipate themselves from patriarchal injustice. International literature deals with the issue as well. It is in line with the same outlook pioneered by Simone de Beauvoir, in the aftermath of the Second World War, and Mariama Bâ, at the dawn of the era of independence in Francophone Africa, that Lopes locates his pro-feminist writing. Women's rights were and continue to be ignored in the author's current environment. Hence, it is for the purpose of restoring women's rights that the author tackles what Michèle Mailhot (1964: 87) refers to as "a pathetic illustration of an inhumane virtue" (l'illustration dérisoire d'une vertu inhumaine), which is not in any way "an expression of a natural order, but rather the reflection of a situation of socio-political inferiority in which women find themselves" (Saint-Martin 1992: 60). ${ }^{31}$

\section{Notes}

1. The status of women around the world is still a burning issue, given that Western literature has always dealt and still deals with this theme from different angles. As early as 1938, the main female character in L'empreinte de mes premières idées (The Mark of My First Ideas) mused about the idea of marriage with a certain degree of apprehension: "Here I am wondering if after my wedding I will be as happy as I am now, or if our love would not vanish, for often marriage is perceived as a kind of charm that quickly starts to kill love. And then, it will all be over, he will no longer lavish my face with passionate kisses, I will no longer experience those minutes during which our actions are driven by sensual pleasure" ("Je me demandais maintenant que si, après mon mariage, je serai aussi heureuse que je le suis présentement, ou si notre amour ne s'envolerait pas, car souvent l'on se représente le mariage comme un charme qui a tôt fait de détruire l'amour. Et alors, ce serait fini, il ne couvrirait plus mon visage de baisers passionnés, je ne connaîtrais plus avec lui ces minutes où le plaisir de la volupté gouverne nos gestes"; Cantin 1938: 126). All the translations from the original are mine.

2. “Rarement a-t-on permis à la sexualité féminine de s'exprimer librement. La situation n'a rien d'étonnant puisque la plupart des histoires d'amour sont racontées du point de vue de l'homme; la femme y joue le rôle de l'autre, de l'objet à conquérir, à courtiser ou à séduire, après quoi le protagoniste se lance vers de nouvelles aventures. Les histoires traditionnelles présentées du point de vue féminin vont généralement dans le même sens, offrant en corollaire la thématique de la femme courtisée et qui résiste jusqu'à ce qu'on lui offre la plus grande récompense: le mariage" (Godard 1992: 85).

3. "Si [...] le narrateur est donné comme féminin et si le focalisateur l'est aussi, alors le roman se propose de nous introduire dans un point de vue de femme, de nous faire entendre une voix féminine, plus ou moins directement." (Borgomano 1989: 81)

4. “- N'oublie pas que tu es une femme. Le premier travail d'une femme c'est le travail domestique [...] - Et vous croyez que c'est avec le Bac qu'elle retiendra son mari à la maison?" (Lopes 1971: 60)

5. "la place d'une jeune fille, d'une future femme est au foyer et non à l'école dont la fréquentation peut porter ombrage à la moralité" (Keita 1976: 28).

6. "se résigner à travailler, souffrir avant l'âge, et laisser les ndumbas aller disserter de l'émancipation de la femme africaine" (Lopes 1971: 17).

7. "il est temps aussi que cessent définitivement les préjugés qui font que certains pères, refusent encore de faire continuer des études à leurs filles et que grâce aux études les femmes se libéreront elles-mêmes de la tyrannie masculine" (Lopes 1971: 55). 
8. "élever sa vision du monde et de cultiver sa personnalité mais aussi de renforcer ses qualités en fructifiant en elle les valeurs de la morale universelle" (Bâ 1980: 27-8).

9. “une employée de maison, chargée de l'approvisionnement, du soin et de la garde d'une progéniture plus nombreuse qu'elle n'aurait souhaitée et qu'elle n'a pas enfantée3 (Lopes 1976: 14).

10. "Adam que Dieu avait dit de gagner son pain à la sueur de son front et non à Eve" (Lopes 1976: 15).

11. "Les femmes ne sont pas de la même espèce que les hommes. Il ne faut pas trop chercher à raisonner avec elles. Elles sont surtout sensitives. Je crois par exemple qu'elles sont sous l'influence de la lune. Comme la mer. Alors, dans ces moments il est inutile de vouloir leur expliquer quoi que ce soit. On perd son temps. Il faut les battre. Bien, bien, bien. Après, ça les soulage. Elles se sentent mieux. Alors, elles peuvent comprendre tout ce qu'on leur dit" (Lopes 1976: 19-20).

12. "audacieuse, effrontée, paroles de diables et de Satan"; "faire bastonner par ses épouses si elle continuait à lui parler" (Keita 1976: 389-90).

13. "les femmes étaient soumises et résignées et ne se mettaient pas à table avec leurs maris qui ne leur faisaient jamais de compliment" (Ben Jelloun 1985: 81).

14. "si la décision ne tenait qu'à elle, elle n'aurait jamais cédé" (Lopes 1971: 48).

15. "l'accroissement du taux de divorces est le résultat de la destruction des structures et des valeurs traditionnelles, sans que de nouvelles aient pris efficacement la relève dans la résolution des problèmes qui se posent aux individus et aux groupes, à l'époque actuelle" (Diop 1985: 211).

16. "les femmes africaines ont un rôle particulier à jouer étant donné qu'elles sont les véritables esclaves" (Lopes 1976: 193).

17. "Changer la vie, transformer le monde, cela voulait dire dessiner un autre horizon, tracer de nouvelles perspectives, refuser l'engluement d'une existence asservie par le travail et le salariat, s'attaquer aux habitudes sociales, contester enfin des comportements sur lesquels d'ordinaire personne ne s'attarde parce qu'ils semblent 'naturels' et aller de soi" (Devésa 1994: 10-1).

18. “opposée à son mari et à travers lui peut-être déjà à cette société où il est considéré comme un homme normal, voire modèle" (Lopes 1976: 191-2).

19. "une force irrésistible, quelque part dans sa poitrine, qui lui répète de couper les liens et de s'en aller" (Lopes 1992: 227).

20. "si elle est la seule, dans le couple, qui soit tenue d'être fidèle" (Lopes 1976: 35).

21. 3"elle sent chaque pore de son corps frémir aux pulsations de la vie" (Mailhot 1964: 54).

22. "Quant aux 'grandes militantes', c'était au fond de sympathiques ndumba de luxe sachant lire et écrire et qui n'iraient pas se battre pour qu'on supprime la polygamie. Elles se moquaient plutôt de ces femmes mariées qui s'imaginaient pouvoir garder un mari pour elles seules" (Lopes 1971: 17).

23. "traduire ndumba ou ndoumba, par 'prostituée' c'est de la malveillance" (Lopes 1992: 64).

24. "Les ndoumbas sont en fait de grandes dames, soucieuses de leur liberté et qui considèrent le mariage comme le cimetière des amours [...] Putains, non! Même si elles veillent à se choisir des amants capables de les aider à vivre dans le confort, nulle parmi elles n'est esclave de l'argent. Elles ne se donnent jamais au plus offrant, mais choisissent leur cavalier (elles en ont souvent plusieurs au même titre que ces hommes de chez nous qui possèdent à la fois plusieurs "deuxièmes bureaux"), le congédient quand l'envie leur en prend, car c'est en y mettant tout son cœur que chacune tient à faire l'amour avec ses hommes" (Lopes 1992: 64).

25. "Les ndoumbas n'étaient pas femmes qu'on sifflait en exhibant quelques billets de banque. Elles choisissaient elles-mêmes leurs proies, fondaient sur elles au moment qu'elles décidaient, les pliaient à leur volonté, les agenouillaient puis les commandaient et les dirigeaient au gré de leurs fantaisies tandis que les épouses fidèles et modèles, tout honorables et vénérables qu'elles fussent, s'étiolaient dans une vie de femme de ménage" (Lopes 1997: 336).

26. "Je choisis mes clients! Ne couche pas avec Elise qui veut, mais qui peut. Observe bien, tu ne verras aucun vieillard parmi mes amants. Tous dans la pleine force de l'âge, ma chère. Quand au nombre, disons que je suis une polygame-femme ... - Une polyandre, rectifia Awa" (Lopes 1976: 66).

27. "les amants s'agenouillent devant elle tout en la traitant continuellement comme une fiancée" (Lopes 1976: 64).

28. "Des êtres mi-femmes, mi-animal. Des sortes de sirènes, belles, très belles, envoûtantes, douées d'un charme irrésistible auquel les papas les plus fidèles ne peuvent résister" (Lopes 1997: 150).

29. "Les femmes libres [...] sont une allusion au problème de la prostitution à Léopoldville et à la coutume clanique de la ndumba. Il était d'usage que l'une des filles de la famille ne soit pas donnée 
en mariage mais pratique, avec l'accord du conseil des anciens, la prostitution afin d'assurer le confort matériel de ses parents, les pères putatifs de ses éventuels enfants constituant une source supplémentaire de revenus, les enfants étant accueillis avec joie puisqu'ils augmentaient le nombre donc l'importance du clan et la force de la communauté" (Houyoux 1993: 52).

30. "Racine et Shakespeare avaient brillamment réussi à mettre sur scène des protagonistes féminins tout comme certaines femmes écrivains réussissent de nos jours à dépeindre brillamment les personnages masculins dans leurs romans" (Lopes 1993: 84).

31. "une expression d'un ordre naturel, mais le reflet d'une situation d'infériorité sociopolitique dans laquelle se trouvent les femmes" (Saint-Martin 1992: 60).

Works cited

Bâ, M. 1980. Une si longue lettre. Dakar-Abidjan-Lomé: Nouvelles Editions Africaines.

Barthes, R. 1966. Critique et vérité. Paris: Seuil.

Beauvoir (De), S.1949. Le deuxième sexe. Tome II. Paris: Gallimard.

Ben Jelloun, T. 1985. Harrouda. Paris: Denoël.

Borgomano, M. 1989. Voix et visages de femmes dans les livres écrits par des femmes en Afrique francophone. Condé-Sur-Noireau: Ceda.

Cantin, A. 1938. L'empreinte de mes premières idées. Montréal: Editions De L'action Canadienne-Française.

Devésa, J.-M.1994. Le Congo des merveilles: surréalisme, magie et conception poétique du monde. In J.-M. Devésa (ed.). Magie et écriture au Congo. Paris. L'harmattan, 9-23.

Diop, A.-B. 1985. La famille wolof: tradition et changement. Paris: Karthala.

Godard, B. Transgressions. In Saint-Martin, L. (ed.). 1992. L'autre Lecture. La Critique Au Féminin Et Les Textes Québécois, Tome I. Montréal: XYZ, 85-95.

Houyoux, S. 1993. Quand Césaire écrit, Lumumba parle. Edition commentée d'Une saison au Congo. Paris: L'harmattan.

Keita, A. 1976. Femme d'Afrique. Paris: Présence Africaine.

Kolawole, M. E. (ed.). 1998. Gender Perceptions And Development In Africa. A Socio-Cultural Approach. Lagos. Arrabon Academic Publischers.

Leskes, A, 1987. Henri Lopes, Tribaliks. Contemporary Congolese Stories. London: Heineman.

Lopes, H. 1971. Tribaliques. Yaoundé: Clé.

1976. La nouvelle romance. Yaoundé: Clé.

1977. Sans tam-tam. Yaoundé: Clé.

1982. Le Pleurer-Rire. Paris: Présence Africaine.

1990. Le chercheur d'Afriques. Paris: Seuil.

1992. Sur l'autre rive. Paris: Seuil.

1993. My novels, my characters and myself. Research in African Literatures, 24 (1): 81-6.

1997. Le Lys et le Flamboyant. Paris: Seuil.

Mailhot, M. 1964. Dis-moi que je vis. Montréal: Le cercle du livre de France. 1967. Le portique. Montréal: Le cercle du livre de France. 